\title{
Barrier Properties of Very Thin Ta and TaN Layers Against Copper Diffusion
}

\author{
M. T. Wang, Y. C. Lin, and M. C. Chen* \\ Department of Electronics Engineering, National Chiao-Tung University, Hsinchu, Taiwan
}

\begin{abstract}
Diffusion barrier properties of very thin sputtered Ta and reactively sputtered TaN films used as a barrier layer between $\mathrm{Cu}$ and $\mathrm{Si}$ substrates were investigated using electrical measurement and materials analysis. The $\mathrm{Cu} / \mathrm{Ta} / \mathrm{p}^{+}-\mathrm{n}$ junction diodes with the Ta barrier of 5,10 , and $25 \mathrm{~nm}$ thicknesses were able to sustain a 30 min thermal annealing at temperatures up to 450,500 , and $550^{\circ} \mathrm{C}$, respectively, without causing degradation to the device's electrical characteristics. The barrier capability of Ta layer can be effectively improved by incorporation of nitrogen in the Ta film using reactive sputtering technique. For the $\mathrm{Cu} / \mathrm{TaN} / \mathrm{p}^{+}-\mathrm{n}$ junction diodes with the TaN barrier of 5,10 , and $25 \mathrm{~nm}$ thicknesses, thermal stability was able to reach 500,600 , and $700^{\circ} \mathrm{C}$, respectively. We found that failure of the very thin Ta and TaN barriers was not related to Ta silicidation at the barrier/Si interface. Failure of the barrier layer is presumably due to Cu diffusion through the barrier layer during the process of thermal annealing via local defects, such as grain boundaries and stress-induced weak points.
\end{abstract}

\section{Introduction}

Copper $(\mathrm{Cu})$ has attracted much attention in deep submicron mutlilevel interconnection applications because of its low bulk resistivity $(1.68 \mu \Omega \mathrm{cm})$, excellent electromigration resistance, ${ }^{1,2}$ and acceptability of deposition by electroless as well as chemical vapor deposition (CVD) $)^{3-5}$ Unfortunately, $\mathrm{Cu}$ diffuses fast in silicon, silicide, as well as oxide, and forms $\mathrm{Cu}-\mathrm{Si}$ compounds at temperatures as low as $200^{\circ} \mathrm{C}$, resulting in degradation of device characteristics. ${ }^{6,7}$ Moreover, it has poor adhesion to interlevel dielectric and drifts through oxide under field acceleration. ${ }^{8-10}$ Therefore, a diffusion barrier between $\mathrm{Cu}$ and its underlying layers is considered as a prerequisite for $\mathrm{Cu}$ to be useful in silicon integrated circuit applications

Various materials have been studied as a diffusion barrier between $\mathrm{Cu}$ and $\mathrm{Si}$ substrate, as well as $\mathrm{Cu}$ and dielectric layer. Refractory metals have been recognized as an attractive class of materials because of their high thermal stability and good electrical conductivity. ${ }^{11-13}$ Sputtering of nitride-based diffusion barriers, such as $\mathrm{WN},{ }^{14} \mathrm{TiN},{ }^{15}$ TiWN ${ }^{16,17}$ and $\mathrm{TaN},{ }^{18-25}$ to be used in $\mathrm{Cu} /$ barrier/Si and $\mathrm{Cu} /$ barrier $/ \mathrm{SiO}_{2}$ structures, has attracted extensive attention. Tantalum (Ta) forms no compound with copper; thus, $\mathrm{Cu} / \mathrm{Ta} / \mathrm{Si}$, structure is expected to be stable at high temperatures..$^{13,19}$ In addition, because $\mathrm{Ta}$ has a low formation enthalpy $(\Delta H)$ with nitrogen, and tantalum nitride (TaN) has a high melting point of $3087^{\circ} \mathrm{C}$ as well as a more dense microstructure, $\mathrm{Cu} / \mathrm{TaN} / \mathrm{Si}$ structure is also expected to be thermally stable at elevated temperatures.$^{26}$ In this work, we investigate $\mathrm{Ta}$ and $\mathrm{TaN}$ as a diffusion barrier in $\mathrm{Cu}$ metallization system.

It was reported that a Ta film of $50 \mathrm{~nm}$ thickness acting as a diffusion barrier between a $\mathrm{Cu}$ and $\mathrm{Si}$ structure retained the integrity of the $\mathrm{Cu} / \mathrm{Ta} / \mathrm{Si}$ structure at temperatures up to $600^{\circ} \mathrm{C}$ for $30 \mathrm{~min} .^{19}$ It was also reported that a TaN film of $100 \mathrm{~nm}$ thickness was able to act as an effective diffusion barrier between $\mathrm{Cu}$ and $\mathrm{Si}$ substrate at $750^{\circ} \mathrm{C}$ for 60 min. ${ }^{23}$ Moreover, it was found that an $\mathrm{Ar}^{+}$ion bombardment during deposition of Ta resulted in a dense Ta film with low resistivity, and thus the barrier effectiveness of Ta film was significantly enhanced. ${ }^{27}$ Although these studies have provided much valuable information for the application of Ta film as a diffusion barrier, nevertheless, little study has been made on the evaluation of barrier effectiveness with respect to the devices' electrical characteristics, which is believed to be more sensitive to barrier degradation than the material property.$^{14}$ Moreover, though a number of data are already published on the thermal stability of Ta and TaN films thicker than $30 \mathrm{~nm}$ using the characterization techniques of material analysis, no comparative study has been made on the thermal stability

* Electrochemical Society Active Member. of ultrathin (less than $30 \mathrm{~nm}$ ) Ta and TaN films using the electrical measurements as well as material analyses. As the device dimensions move to $0.25 \mu \mathrm{m}$ and below, it becomes inappropriate to use a barrier thicker than $30 \mathrm{~nm}$. The barrier thickness should be reduced to lower the resistance of the total line interconnect and/or via.

In this study, we investigated the thermal stability of ultrathin $\mathrm{Ta}$ and $\mathrm{TaN}$ barrier layers in a $\mathrm{Cu}$ metallization system. Properties of these barrier layers were evaluated by electrical measurement as well as material analyses. The results of this study might be useful for $\mathrm{Cu}$ metallization in ultralarge-scale integrated (ULSI) multilevel interconnects applications.

\section{Experimental}

The $\mathrm{Cu} / \mathrm{Ta} / \mathrm{p}^{+}-\mathrm{n}$ and $\mathrm{Cu} / \mathrm{TaN} / \mathrm{p}^{+}-\mathrm{n}$ junction diodes were fabricated for the study of $\mathrm{Ta}$ and $\mathrm{TaN}$ barrier capability The starting materials were 4-in., (100)-oriented, n-type silicon wafers with $4-7 \Omega \mathrm{cm}$ nominal resistivity. After RCA standard cleaning, the wafers were thermally oxidized at $1050^{\circ} \mathrm{C}$ in steam atmosphere to grow a $500 \mathrm{~nm}$ oxide layer. Diffusion regions with areas $500 \times 500$ and $1000 \times 1000 \mu^{2}$ were defined on the oxide-covered wafers using the conventional photolithographic technique. The $\mathrm{p}^{+}-\mathrm{n}$ junctions with junction depths of $0.3 \mu \mathrm{m}$ were formed by $\mathrm{BF}_{2}^{+}$implantation at $40 \mathrm{keV}$ to a dose of $3 \times 10^{15} \mathrm{~cm}^{-2}$ followed by furnace annealing at $900^{\circ} \mathrm{C}$ for 30 min in $\mathrm{N}_{2}$ ambient.

After the junctions were formed, the wafers were prepared for Ta or TaN barrier layer deposition. In this study, a dc magnetron sputtering system with a base pressure of $1-2 \times 10^{-6}$ Torr and with no intentional substrate heating and bias was used. The Ta films were sputtered using a Ta target in Ar ambient at a pressure of $7.6 \mathrm{mTorr}$, while the TaN films were reactively sputtered using the same Ta target in an $\mathrm{Ar} / \mathrm{N}_{2}$ gas mixture at the same pressure of 7.6 mTorr. The flow rates of $\mathrm{Ar}$ and $\mathrm{N}_{2}$ into the sputtering chamber were 24 and $6 \mathrm{sccm}$, respectively, for making the $\mathrm{Ar} / \mathrm{N}_{2}$ gas mixture. ${ }^{28}$ Prior to each sputter deposition, the target was cleaned by presputtering with the shutter closed for $10 \mathrm{~min}$. The Ta and TaN films were deposited at a sputtering power of $200 \mathrm{~W}$ to a thickness of 25,10 , and $5 \mathrm{~nm}$ separately. The deposition rates of $\mathrm{Ta}$ and $\mathrm{TaN}$ films were determined to be 2.94 and $2.07 \mathrm{~nm} / \mathrm{min}$, respectively. After the barrier layer deposition, $\mathrm{Cu}$ films of $200 \mathrm{~nm}$ thickness were deposited on the barrier metal using the same sputtering system without breaking the vacuum. Finally, $\mathrm{Cu}$ patterns were defined and etched using dilute (5 vol \%) $\mathrm{HNO}_{3}$, while Ta and Ta nitrides were etched using $\mathrm{SF}_{6} / \mathrm{N}_{2}$ plasma for the preparation of $\mathrm{Cu} / \mathrm{Ta} / \mathrm{p}^{+}-\mathrm{n}$ and $\mathrm{Cu} / \mathrm{TaN} / \mathrm{p}^{+}-$ $n$ diodes. For comparison, the thermal stability of $\mathrm{Cu} / \mathrm{p}^{+}-\mathrm{n}$ diodes without a barrier layer as well as $\mathrm{Ta} / \mathrm{p}^{+}-\mathrm{n}$ and $\mathrm{TaN} / \mathrm{p}^{+}-\mathrm{n}$ diodes without a $\mathrm{Cu}$ overlayer was also investi- 
gated. The schematic cross sections of these differently metallized $\mathrm{p}^{+}-\mathrm{n}$ junction diodes are illustrated in Fig. 1.

To investigate thermal stability of the $\mathrm{Cu} / \mathrm{Ta} / \mathrm{p}^{+}-\mathrm{n}$ and $\mathrm{Cu} / \mathrm{TaN} / \mathrm{p}^{+}-\mathrm{n}$ diodes, the diodes were thermally annealed at various temperatures ranging from 200 to $800^{\circ} \mathrm{C}$ for $30 \mathrm{~min}$ in $\mathrm{N}_{2}$ ambient. Leakage current was measured at a reverse bias of $-5 \mathrm{~V}$ using an HP-4145B semiconductor parameter analyzer; the measured diodes have an active area of $500 \times$ 500 or $1000 \times 1000 \mu \mathrm{m}$, and at least 30 diodes were measured in each case. For material analysis, unpatterned samples of barrier/Si, Cu/barrier/Si, and $\mathrm{Cu} /$ barrier $/ \mathrm{SiO}_{2} / \mathrm{Si}$ structures were also prepared. These samples were processed in the same process run with the patterned samples of junction diodes except a number of thicker Ta and TaN samples of $\mathrm{Ta} / \mathrm{Si}$ and $\mathrm{TaN} / \mathrm{Si}$ specialized for X-ray diffraction (XRD) analysis. Sheet resistance of the multilayer structures was measured using a four-point probe. XRD analysis using a $30 \mathrm{keV}$ copper $\mathrm{K} \alpha$ radiation was used for phase identification. Scanning electron microscopy (SEM) was employed to observe surface morphology and microstructure.

\section{Results and Discussion}

Electrical measurements.-Barrier capability of thin Ta and TaN films was investigated by evaluating the thermal stability of $\mathrm{Cu} / \mathrm{Ta} / \mathrm{p}^{+}-\mathrm{n}$ and $\mathrm{Cu} / \mathrm{TaN} / \mathrm{p}^{+}-\mathrm{n}$ junction diodes using electrical measurements. We analyzed the distributions of leakage current density for the annealed diodes and related the results of electrical measurements to other results obtained by sheet resistance measurement, XRD analysis, and SEM observation.

$\mathrm{Cu} / \mathrm{Ta} / \mathrm{p}^{*}-n$ junction diodes.-Figure 2 illustrates the statistical distributions of reverse bias leakage current density measured at $-5 \mathrm{~V}$ for the $\mathrm{Cu} / \mathrm{Ta}(25 \mathrm{~nm}) / \mathrm{p}^{+}-\mathrm{n}, \mathrm{Cu} / \mathrm{Ta}$ $(10 \mathrm{~nm}) \mathrm{p}^{+}-\mathrm{n}$, and $\mathrm{Cu} / \mathrm{Ta}(5 \mathrm{~nm}) / \mathrm{p}^{+}-\mathrm{n}$ junction diodes annealed at various temperatures. The $\mathrm{Cu} / \mathrm{Ta}(25 \mathrm{~nm}) / \mathrm{p}^{+}-\mathrm{n}$ diodes remained stable after annealing at temperatures up to $550^{\circ} \mathrm{C}$ but suffered moderate degradation in electrical characteristic at $600^{\circ} \mathrm{C}$; annealing at $650^{\circ} \mathrm{C}$ resulted in severe degradation (Fig. 2a). For the $\mathrm{Cu} / \mathrm{Ta}(10 \mathrm{~nm}) / \mathrm{p}^{+}-\mathrm{n}$ diodes, the diodes remained stable after annealing at tem-

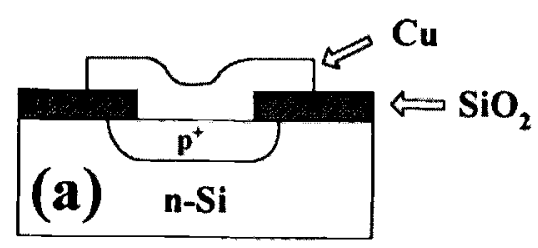

$\mathrm{Cu} / \mathrm{p}^{+}-\mathrm{n}$ diode

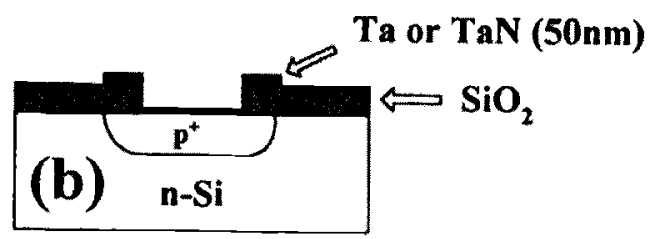

$\mathrm{Ta} / \mathrm{p}^{+}-\mathrm{n}$ or $\mathrm{TaN} / \mathrm{p}^{+}-\mathrm{n}$ diode

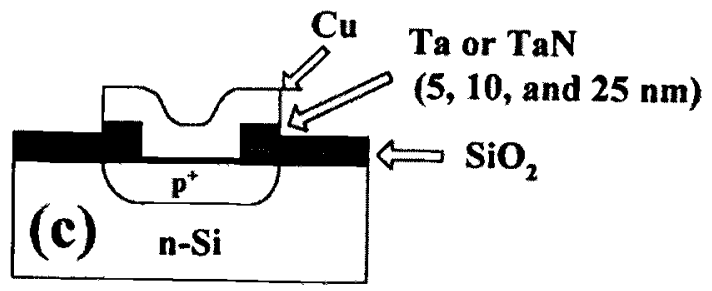

\section{$\mathrm{Cu} / \mathrm{Ta} / \mathrm{p}^{+}-\mathrm{n}$ or $\mathrm{Cu} / \mathrm{TaN} / \mathrm{p}^{+}-\mathrm{n}$ diode}

Fig. 1. Schematic cross sections of (a) $\mathrm{Cu} / \mathrm{p}^{+}-n,(\mathrm{~b})$ barrier $/ \mathrm{p}^{+}-n$, and $(c) \mathrm{Cu} /$ barrier $/ \mathrm{p}^{+}-\mathrm{n}$ junction diodes.

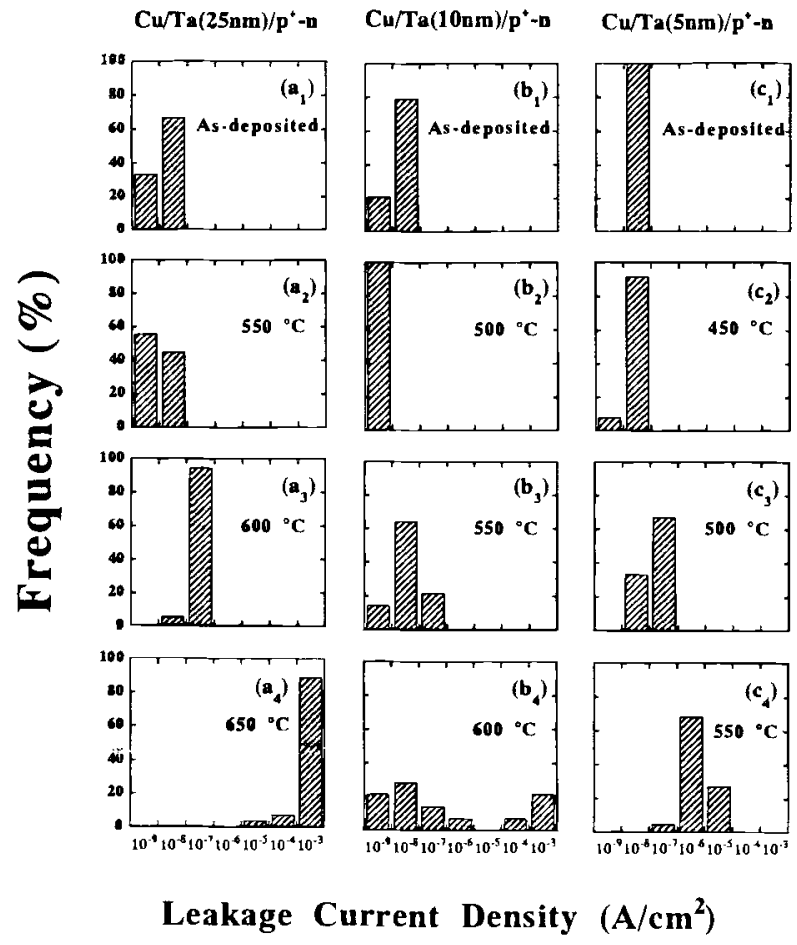

Fig. 2. Histograms showing the distributions of reverse bias leakage current density for (a) $\mathrm{Cu} / \mathrm{Ta}(25 \mathrm{~nm}) / \mathrm{p}^{+}-\mathrm{n}$, (b) $\mathrm{Cu} / \mathrm{Ta}$ $(10 \mathrm{~nm}) / \mathrm{p}^{+}-n$, and $(\mathrm{c}) \mathrm{Cu} / \mathrm{Ta}(5 \mathrm{~nm}) / \mathrm{p}^{+}-n$ junction diodes annealed at various temperatures.

peratures up to $500^{\circ} \mathrm{C}$, while a number of diodes suffered moderate degradation after annealing at $550^{\circ} \mathrm{C}$; however, about $50 \%$ of the diodes survived even after annealing at $600^{\circ} \mathrm{C}$ (Fig. 2b). As for the $\mathrm{Cu} / \mathrm{Ta}(5 \mathrm{~nm}) / \mathrm{p}^{+}-\mathrm{n}$ diodes, they started to show degradation after annealing at $500^{\circ} \mathrm{C}$ (Fig. 2c). This indicates that thermal stability of the $\mathrm{Cu} / \mathrm{Ta} / \mathrm{p}^{+}-\mathrm{n}$ junction diodes may be severely degraded by reducing the Ta barrier layer thickness below $5 \mathrm{~nm}$.

$\mathrm{Cu} / \mathrm{TaN}^{\mathrm{N}} \mathrm{p}^{+}-n$ junction diodes.-The barrier properties of Ta can be significantly improved by adding impurities, such as $\mathrm{N}$ and $\mathrm{O}$, to the Ta film. ${ }^{18,19}$ If solubility limit of the impurity is exceeded, solute atoms in the Ta grain are expected to be segregated to the grain boundaries, resulting in obstruction of the fast paths for copper diffusion. It was reported that the grain size and atomic density of reactively sputtering deposited Ta- $\mathrm{N}$ films, respectively, decreased and increased as the nitrogen concentration in the $\mathrm{Ta}-\mathrm{N}$ films was increased; moreover, the bcc- $\mathrm{Ta}, \mathrm{Ta}_{2} \mathrm{~N}$, $\mathrm{TaN}$, and $\mathrm{Ta}_{5} \mathrm{~N}_{6}$ phase appeared in succession with the increase of the nitrogen content. ${ }^{18}$ In addition, TaN is chemically inert to $\mathrm{Si}$ and $\mathrm{Cu}$, and it has been reported that the contact system of $\mathrm{Cu} / \mathrm{TaN} / \mathrm{Si}$ is thermally very stable. ${ }^{23}$ The superiority of TaN films in thermal stability over the pure Ta film was also reported. ${ }^{20}$

Figure 3 shows the statistical distributions of reverse bias leakage current density for the $\mathrm{Cu} / \mathrm{TaN} / \mathrm{p}^{+}-\mathrm{n}$ junction diodes of different TaN barrier thickness annealed at various temperatures. For the diodes with a $25 \mathrm{~nm}$ thick TaN barrier, the devices remained stable after annealing at temperatures up to $700^{\circ} \mathrm{C}$. After annealing at $750^{\circ} \mathrm{C}$, though many devices failed, more than half of the tested diodes still survived (Fig. 3a). This feature of failure is probably related to the $\mathrm{Cu}$ diffusion through localized defects in the annealed TaN layer. For the diodes with a $10 \mathrm{~nm}$ thick TaN barrier, the devices suffered moderate degradation after annealing at $650^{\circ} \mathrm{C}$ and degraded severely after annealing at $700^{\circ} \mathrm{C}\left(\mathrm{Fig}\right.$. 3b). For the $\mathrm{Cu} / \mathrm{TaN}(5 \mathrm{~nm}) / \mathrm{p}^{+}-\mathrm{n}$ diodes, the $5 \mathrm{~nm}$ TaN film was proved to be an effective barrier against $\mathrm{Cu}$ diffusion at temperatures up to $500^{\circ} \mathrm{C}$. As the annealing temperature was raised to $550^{\circ} \mathrm{C}$, the diodes started to show degradation (Fig. 3c). Comparative results 


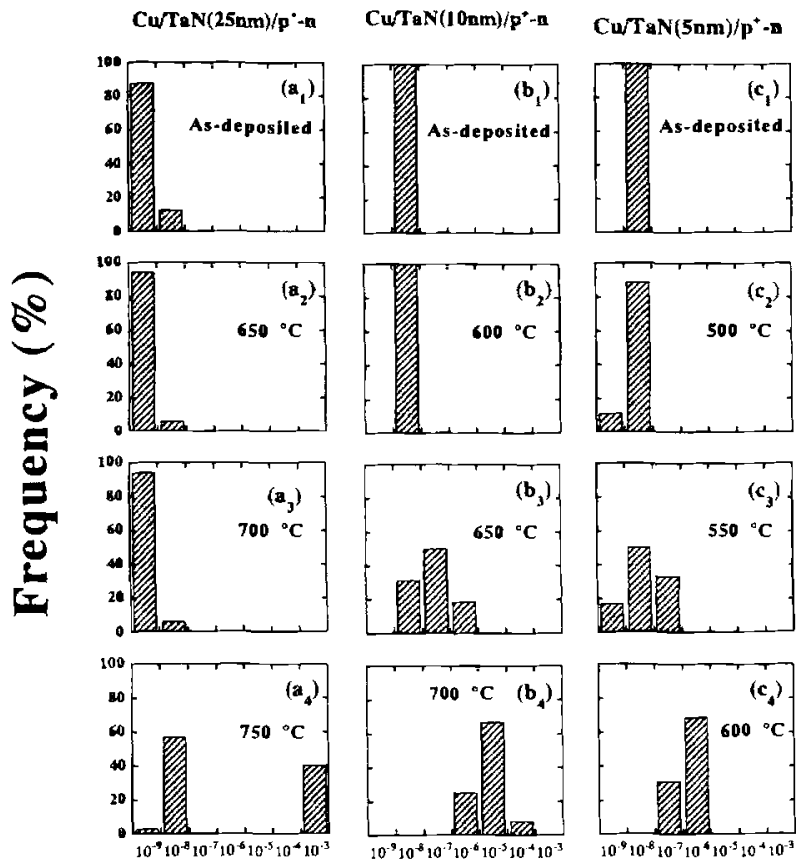

Leakage Current Density $\left(\mathrm{A} / \mathrm{cm}^{2}\right)$

Fig. 3. Histograms showing the distributions of reverse bias leakage current density for (a) $\mathrm{Cu} / \operatorname{TaN}(25 \mathrm{~nm}) / \mathrm{p}^{+}-n$, (b) $\mathrm{Cu} / \mathrm{TaN}$ $(10 \mathrm{~nm}) / \mathrm{p}^{+}-n$, and $(c) \mathrm{Cu} / \operatorname{TaN}(5 \mathrm{~nm}) / \mathrm{p}^{+}-n$ junction diodes annealed at various temperatures.

of barrier effectiveness for $\mathrm{Ta}$ and $\mathrm{TaN}$ films of different thickness are summarized in Table I. The results show that the barrier capability of a Ta layer can be substantially improved by incorporation of nitrogen using reactive nitridation technique. Moreover, thermal stability of the $\mathrm{Cu} / \mathrm{Ta} / \mathrm{p}^{+}-\mathrm{n}$ and $\mathrm{Cu} / \mathrm{TaN} / \mathrm{p}^{+}-\mathrm{n}$ diodes was found to be dependent on the thickness of the barrier, implying that $\mathrm{Cu}$ diffusion in the barrier layer is mainly controlled by film defects, such as grain boundaries, voids, and dislocations.

$\mathrm{Cu} / \mathrm{p}^{+}-n, \mathrm{Ta} / \mathrm{p}^{+}-n$, and $\mathrm{TaN} / \mathrm{p}^{*}-n$ junction diodes.-For comparison, the $\mathrm{Cu} / \mathrm{p}^{+}-\mathrm{n}$ diodes without a barrier layer and the barrier $/ \mathrm{p}^{+}-\mathrm{n}$ diodes without a $\mathrm{Cu}$ overlayer were also fabricated for thermal stability study. Figure 4 illustrates the distributions of reverse bias leakage current density for the $\mathrm{Cu} / \mathrm{p}^{+}-\mathrm{n}, \mathrm{Ta} / \mathrm{p}^{+}-\mathrm{n}$, and $\mathrm{TaN} / \mathrm{p}^{+}-\mathrm{n}$ junction diodes annealed at various temperatures. The $\mathrm{Cu} / \mathrm{p}^{+}-\mathrm{n}$ diodes suffered severe degradation after annealing at $200^{\circ} \mathrm{C}$ (Fig. 4a), while the Ta/p $\mathrm{p}^{+}-\mathrm{n}$ and $\mathrm{TaN} / \mathrm{p}^{+}-\mathrm{n}$ diodes were able to retain their integrity up to at least $800^{\circ} \mathrm{C}$. Thus, the degradation of $\mathrm{Cu} / \mathrm{Ta} / \mathrm{p}^{+}-\mathrm{n}$ and $\mathrm{Cu} / \mathrm{TaN} / \mathrm{p}^{+}-\mathrm{n}$ diodes (Fig. 2 and 3) was attributed to the presence of $\mathrm{Cu}$ overlayer.

Material Analyses.-XRD analysis.-The crystallographic structure of sputter-deposited $\mathrm{TaN}_{x}$ depends on the concentration of nitrogen in the $\mathrm{TaN}_{x}$ film. ${ }^{18,19}$ Figure 5 shows the XRD spectra for the $\mathrm{Ta}(300 \mathrm{~nm}) / \mathrm{Si}$ sample annealed at various temperatures. Diffraction patterns taken from the as-deposited Ta layer was indexed to be $\beta-T a{ }^{29}$ For the sample annealed at $650^{\circ} \mathrm{C}$, the spectrum remained unchanged as compared with the as-deposited sample. However, a number of weak $\mathrm{TaSi}_{2}{ }^{30}$ peaks appeared for the

Table I. Comparative results of barrier effectiveness for Ta and TaN films evaluated by electrical measurement on the $\mathrm{Cu} /$ barrier $/ \mathrm{p}^{+}-\mathrm{n}$ junction diodes.

\begin{tabular}{|c|c|c|c|c|c|c|}
\hline \multirow[b]{2}{*}{ Barrier layer } & \multicolumn{3}{|c|}{$\mathrm{Ta}$} & \multicolumn{3}{|c|}{$\mathrm{TaN}$} \\
\hline & $25 \mathrm{~nm}$ & $10 \mathrm{~nm}$ & $5 \mathrm{~nm}$ & $25 \mathrm{~nm}$ & $10 \mathrm{~nm}$ & $5 \mathrm{~nm}$ \\
\hline $\begin{array}{l}\text { Thermal stability } \\
\text { temperature }\end{array}$ & $550^{\circ} \mathrm{C}$ & $500^{\circ} \mathrm{C}$ & $450^{\circ} \mathrm{C}$ & $700^{\circ} \mathrm{C}$ & $600^{\circ} \mathrm{C}$ & $500^{\circ} \mathrm{C}$ \\
\hline
\end{tabular}

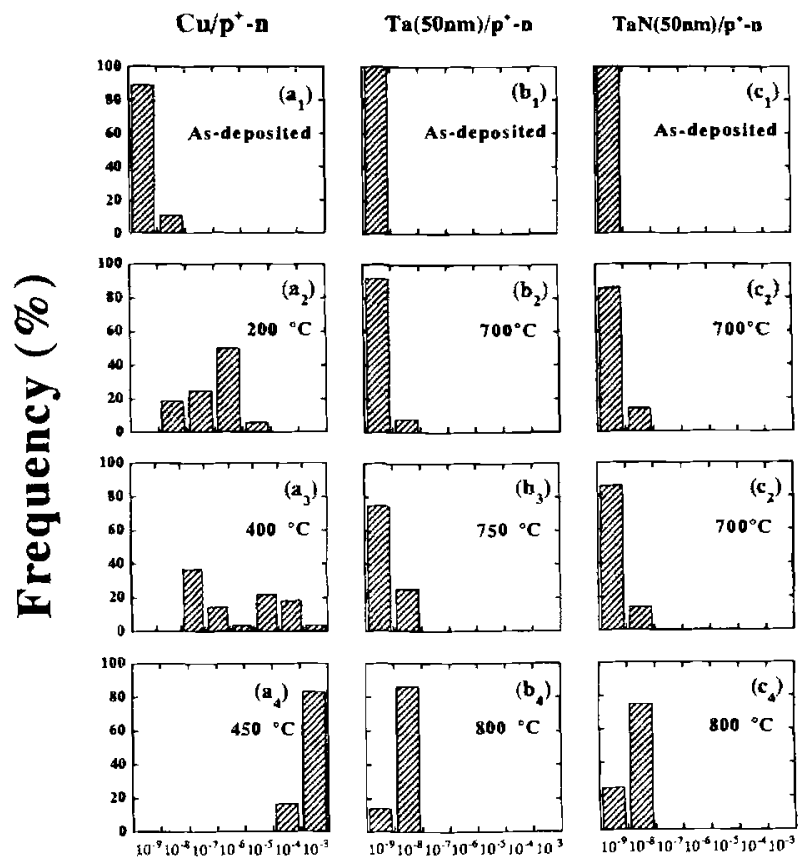

Leakage Current Density $\left(A / \mathrm{cm}^{2}\right)$

Fig. 4. Histograms showing the distributions of reverse bias leakage current density for (a) $\mathrm{Cu} / \mathrm{p}^{+}-n$, (b) $\mathrm{Ta}(50 \mathrm{~nm}) / \mathrm{p}^{+}-n$, and $(\mathrm{c})$ $\operatorname{TaN}(50 \mathrm{~nm}) / \mathrm{p}^{+}-\mathrm{n}$ junction diodes annealed at various temperatures.

sample annealed at $700^{\circ} \mathrm{C}$. After annealing at $800^{\circ} \mathrm{C}$, signals representing the crystalline phase of $\mathrm{TaSi}_{2}$ became much stronger, indicating significant grain growth. Since Ta silicidation was not observed at $600^{\circ} \mathrm{C}$ and the electrical characteristics of $\mathrm{Cu} / \mathrm{Ta} / \mathrm{p}^{+}-\mathrm{n}$ diodes failed at temperatures below $600^{\circ} \mathrm{C}$ (Fig. 2), we excluded the possibility of Ta silicidation to be one of the Ta-barrier failure mechanisms for the $\mathrm{Cu} / \mathrm{Ta} / \mathrm{p}^{+}-\mathrm{n}$ junction diodes. Noya et al. reported that $\mathrm{Ta}_{5} \mathrm{Si}_{3}$ or amorphous layer formation at the $\mathrm{Ta} / \mathrm{Si}$ interface preceded the $\mathrm{TaSi}_{2}$ growth. ${ }^{31,32}$ However, our results of XRD analyses showed only $\mathrm{TaSi}_{2}$ phase in the thermally annealed

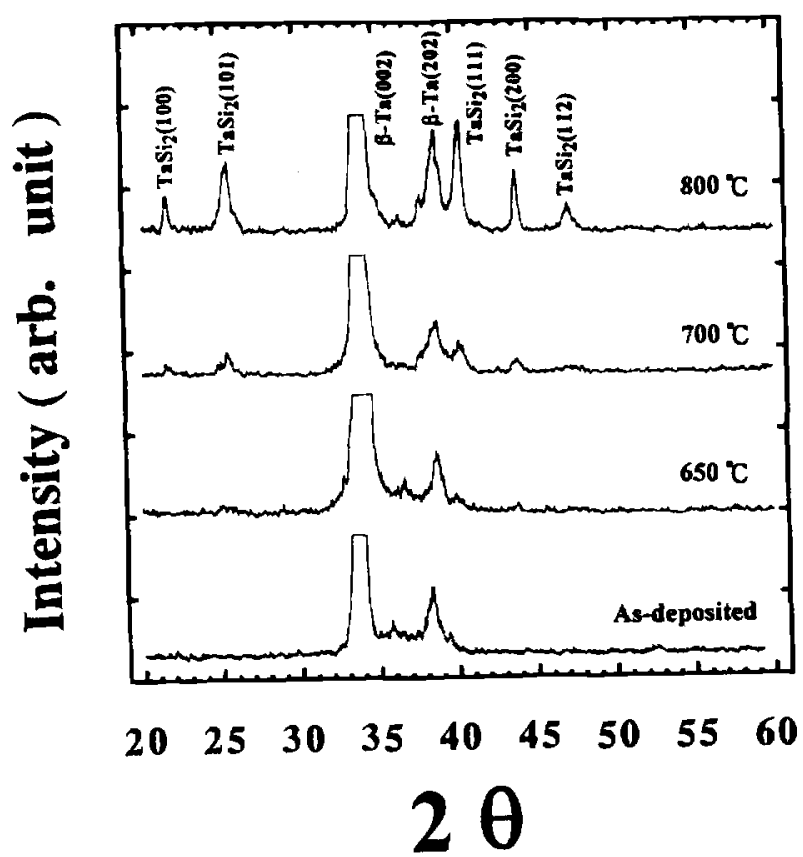

Fig. 5. XRD spectra for Ta $(300 \mathrm{~nm}) / \mathrm{Si}$ sample annealed at various temperatures. 
$\mathrm{Ta} / \mathrm{Si}$ system, similar to the results reported by Holloway et $\mathrm{al}^{20}$ This discrepancy might result from the difference in deposition temperature as well as thickness of Ta metal and annealing conditions between Noya's and ours.

Figure 6 shows XRD spectra for the TaN $(300 \mathrm{~nm}) / \mathrm{Si}$ sample. The diffraction patterns taken from the asdeposited TaN layer was indexed to be cubic TaN. ${ }^{33}$ The spectrum remained unchanged even after the sample was annealed at $800^{\circ} \mathrm{C}$, indicating structural integrity of the $\mathrm{TaN}(300 \mathrm{~nm}) / \mathrm{Si}$ sample. By comparing the XRD spectra of the TaN/Si samples (Fig. 6) with those of the Ta/Si samples (Fig. 5), we found clearly that the contact system of TaN/Si is chemically more stable than that of $\mathrm{Ta} / \mathrm{Si}$.

Figure $T$ shows XRD spectra for the $\mathrm{Cu} / \mathrm{Ta}(25 \mathrm{~nm}) / \mathrm{Si}$ and $\mathrm{Cu} / \mathrm{TaN}(25 \mathrm{~nm}) / \mathrm{Si}$ samples after annealing at various temperatures. For the $\mathrm{Cu} / \mathrm{Ta} / \mathrm{Si}$ sample annealed at $650^{\circ} \mathrm{C}$, signal of $\mathrm{Ta}_{5} \mathrm{Si}_{3}$ phase ${ }^{34}$ was detected; after annealing at $750^{\circ} \mathrm{C}$, signal of $\mathrm{Cu}^{35}$ disappeared while many peaks relating to $\mathrm{Ta}$ silicide and $\mathrm{Cu}$ silicide ${ }^{36}$ appeared, indicating complete failure of the Ta-barrier film (Fig. 7a). Compared with the XRD spectra for the Ta/Si samples (Fig. 5), we found that the presence of $\mathrm{Cu}$ film on the surface of the $\mathrm{Ta} / \mathrm{Si}$ structure accelerated the formation of Ta silicide. ${ }^{20}$ Silicide signals did not appear for the $\mathrm{Cu} / \mathrm{TaN} / \mathrm{Si}$ sample thermally annealed at temperatures up to $750^{\circ} \mathrm{C}$ (Fig. 7b). Clearly, thermal stability of the $\mathrm{Cu} / \mathrm{TaN} / \mathrm{Si}$ structure is superior to that of the $\mathrm{Cu} / \mathrm{Ta} / \mathrm{Si}$ contact system. Furthermore, raising the annealing temperature to $800^{\circ} \mathrm{C}$ resulted in the appearance of $\mathrm{Cu}$ silicide signal, but the Ta silicide signal was not detected (Fig. 7b). These results imply that the failure of $\mathrm{Cu} / \mathrm{TaN} / \mathrm{p}^{+}-\mathrm{n}$ diodes at $750^{\circ} \mathrm{C}$ or below (Fig. 3) was not related to Ta silicidation at the TaN/Si interface. Instead, $\mathrm{Cu}$ atoms diffused through the annealed $\mathrm{TaN}$ film via local defects (such as grain boundaries, voids, and stress-induced weak points) should be blamed.

Sheet resistance measurement.-The sheet resistance change of annealed samples, normalized to the as-deposited sheet resistance value, is denoted as $\Delta R s / R s \%$ and defined as follows

$$
\frac{\Delta R s}{R s} \%=\frac{R s_{\text {after anncal }}-R s_{\text {as-dep osited }}}{R s_{\text {as-rleposited }}} \times 100 \%
$$

Figure 8 shows the percentage change of sheet resistance vs. annealing temperature for the samples of $\mathrm{Cu} / \mathrm{Ta}$

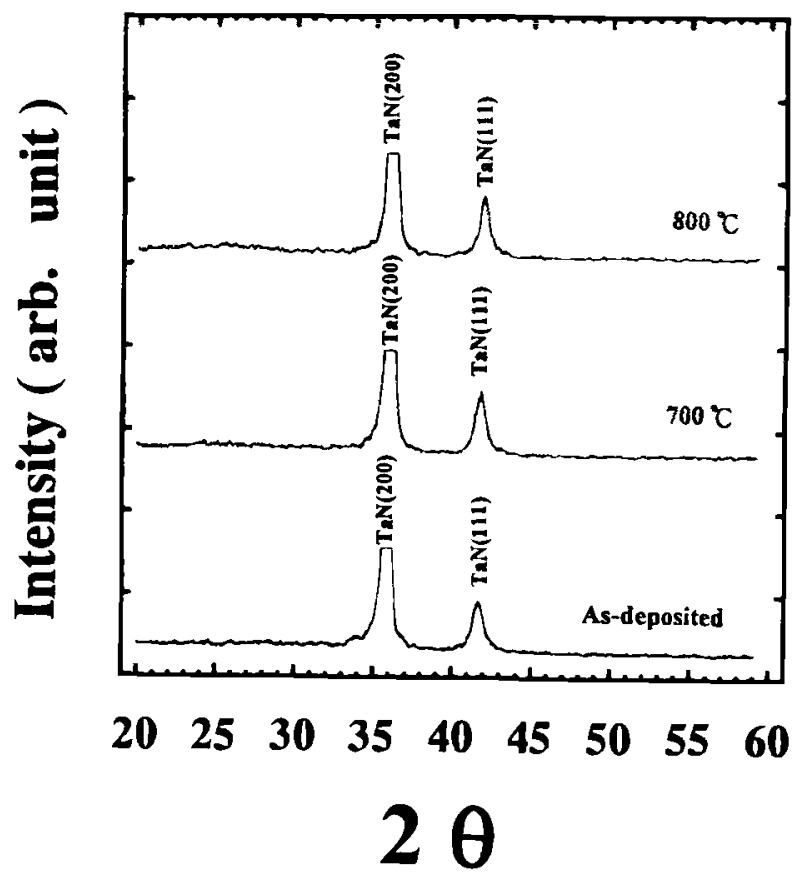

Fig. 6. XRD spectra for $\mathrm{TaN}(300 \mathrm{~nm}) / \mathrm{Si}$ sample annealed at various temperatures.
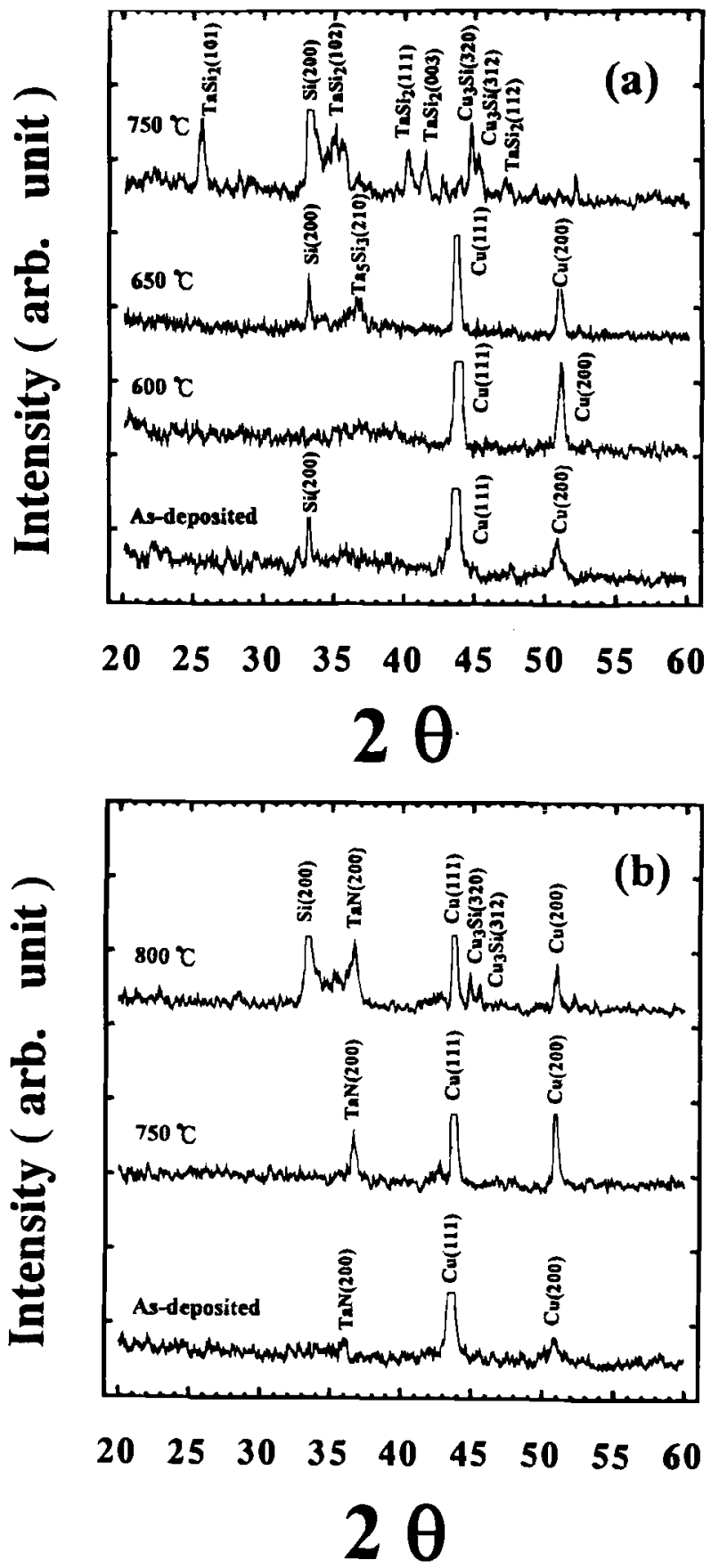

Fig. 7. XRD spectra for (a) $\mathrm{Cu} / \mathrm{Ta}(25 \mathrm{~nm}) / \mathrm{Si}$ and (b) $\mathrm{Cu} / \mathrm{TaN}$ $(25 \mathrm{~nm}) / \mathrm{Si}$ samples annealed at various temperatures.

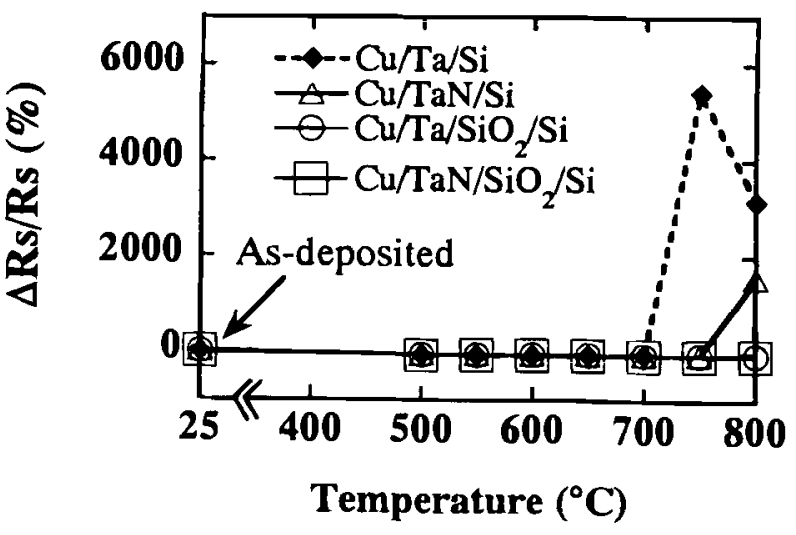

Fig. 8. Percentoge change of sheet resistance vs. annealing temperature for the samples of $\mathrm{Cu} / \mathrm{Ta}(25 \mathrm{~nm}) / \mathrm{Si}, \mathrm{Cu} / \mathrm{TaN}(25 \mathrm{~nm}) / \mathrm{Si}$, $\mathrm{Cu} / \mathrm{Ta}(25 \mathrm{~nm}) / \mathrm{SiO}_{2} / \mathrm{Si}$, and $\mathrm{Cu} / \mathrm{TaN}(25 \mathrm{~nm}) / \mathrm{SiO}_{2} / \mathrm{Si}$. 
Table II. Compound phases detected by XRD analysis for various multilayer structures studied in this work. ${ }^{\circ}$

\begin{tabular}{ccccc}
\hline \multirow{2}{*}{$\begin{array}{c}\text { Annealing } \\
\text { temperature }\end{array}$} & \multicolumn{3}{c}{ Samples structure } \\
\cline { 2 - 5 } & $\mathrm{Ta} / \mathrm{Si}$ & $\mathrm{TaN} / \mathrm{Si}$ & $\mathrm{Cu} / \mathrm{Ta} / \mathrm{Si}$ & $\mathrm{Cu} / \mathrm{TaN} / \mathrm{Si}$ \\
\hline $600^{\circ} \mathrm{C}$ & $\times$ & $\times$ & $\times$ & $\times$ \\
$650^{\circ} \mathrm{C}$ & $\times$ & $\times$ & $\mathrm{Ta}_{5} \mathrm{Si}_{3}$ & $\times$ \\
$700^{\circ} \mathrm{C}$ & $\mathrm{TaSi}_{2}$ & $\times$ & $\mathrm{Cu}_{3} \mathrm{Si} \mathrm{Ta}_{5} \mathrm{Si}_{3}$ & $\times$ \\
$750^{\circ} \mathrm{C}$ & $\mathrm{TaSi}_{2}$ & $\times$ & $\times$ & $\times$ \\
$800^{\circ} \mathrm{C}$ & $\mathrm{TaSi}_{2}$ & $\times$ & $\mathrm{Cu}_{3} \mathrm{Si}_{2} \mathrm{TaSi}_{2}, \mathrm{Ta}_{5} \mathrm{Si}_{3}$ & $\times$ \\
$\mathrm{Cu}_{3} \mathrm{Si}_{2} \mathrm{TaSi}_{2}$ & $\times$ & $\times$ \\
$\mathrm{Cu}$ & $\times$ & $\times$ \\
\end{tabular}

a " $\times$ " indicates no observation of compound phase (except TaN).

$(25 \mathrm{~nm}) / \mathrm{Si}, \mathrm{Cu} / \mathrm{TaN}(25 \mathrm{~nm}) / \mathrm{Si}, \mathrm{Cu} / \mathrm{Ta}(25 \mathrm{~nm}) / \mathrm{SiO}_{2} / \mathrm{Si}$, and $\mathrm{Cu} / \mathrm{TaN}(25 \mathrm{~nm}) / \mathrm{SiO}_{2} / \mathrm{Si}$. For the $\mathrm{Cu} / \mathrm{Ta}(25 \mathrm{~nm}) / \mathrm{Si}$ sample,
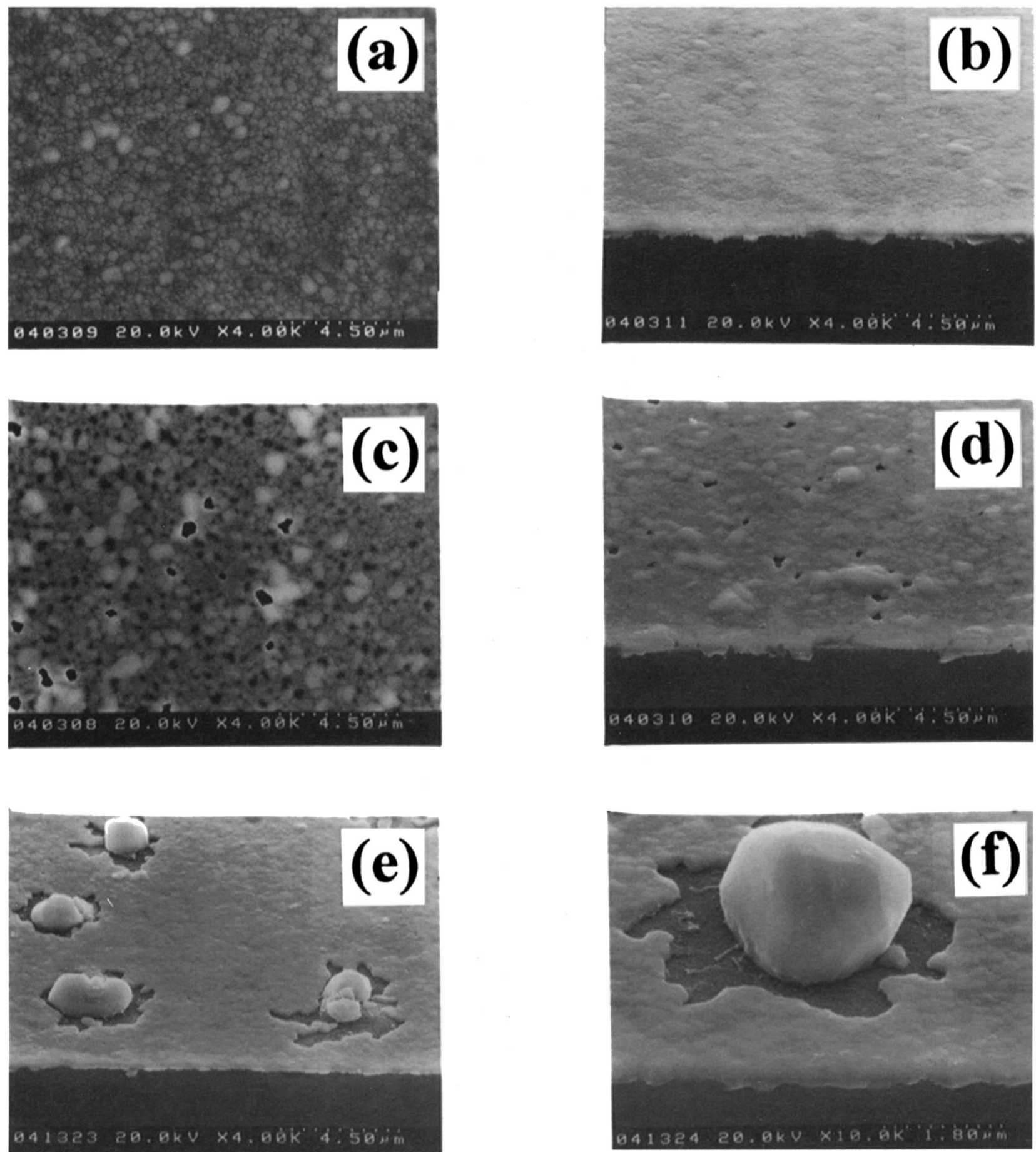

Fig. 9. Top view and oblique view SEM micrographs for the $\mathrm{Cu} / \mathrm{TaN}(25 \mathrm{~nm}) / \mathrm{p}^{+}-\mathrm{n}$ diodes annealed at (a) and (b) $700^{\circ} \mathrm{C}$, and $(\mathrm{c})$, (d), (e), and $(f) 750^{\circ} \mathrm{C}$. The micrographs $(c)$ and $(d)$ were taken on a slightly degraded diode, and $(e)$ and $(f)$ were taken on a severely degraded diode. 

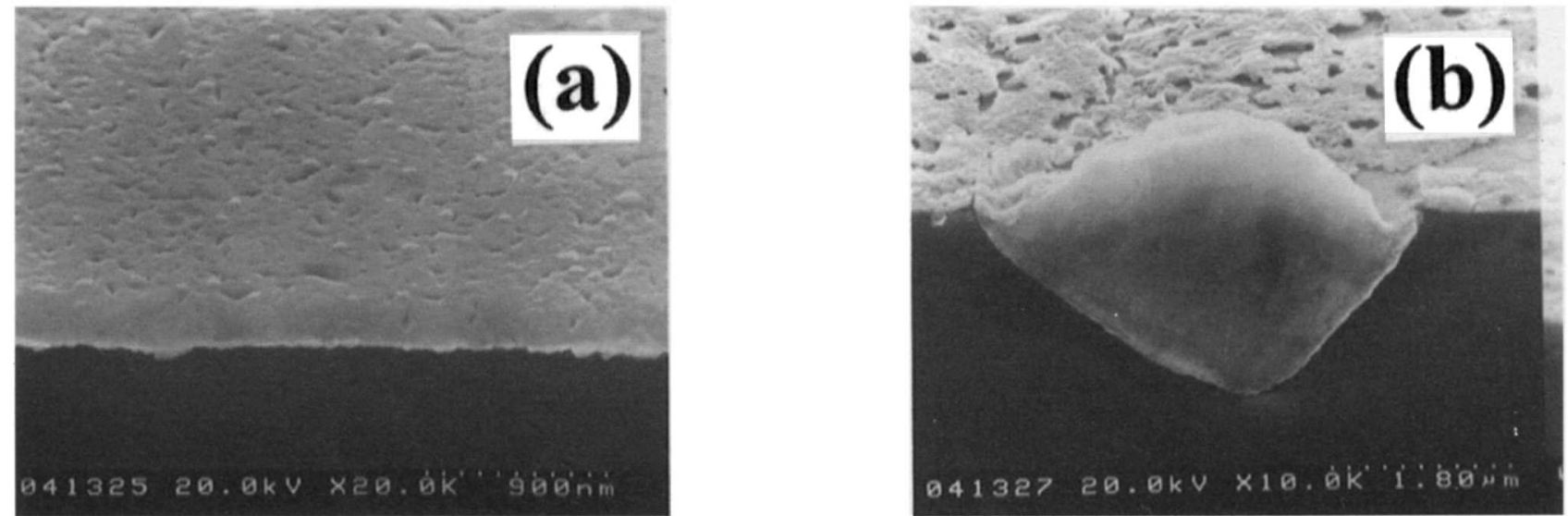

Fig. 10. SEM micrographs for the $\mathrm{Cu} / \mathrm{Ta}(25 \mathrm{~nm}) / \mathrm{p}^{+}-\mathrm{n}$ diodes annealed at (a) 600 and $(\mathrm{b}) 650^{\circ} \mathrm{C}$.

after annealing at $750^{\circ} \mathrm{C}$. Sheet resistance for the $\mathrm{Cu} /$ $\mathrm{TaN}(25 \mathrm{~nm}) / \mathrm{Si}$ sample remained unchanged after annealing at temperatures up to $750^{\circ} \mathrm{C}$ but made a significant increase after annealing at $800^{\circ} \mathrm{C}$. The increase in sheet resistance for the $\mathrm{Cu} / \mathrm{Ta}(25 \mathrm{~nm}) / \mathrm{Si}$ and $\mathrm{Cu} / \mathrm{TaN}(25 \mathrm{~nm}) / \mathrm{Si}$ samples reflects the consumption of conductive $\mathrm{Cu}$ layer due to $\mathrm{Cu}_{3} \mathrm{Si}$ formation, as confirmed by the XRD analysis shown in Fig. 7. Although sheet resistance of the $\mathrm{Cu} / \mathrm{Ta}$ $(25 \mathrm{~nm}) / \mathrm{Si}$ sample remained unchanged after annealing at $700^{\circ} \mathrm{C}$, the results of electrical measurement showed that the $\mathrm{Cu} / \mathrm{Ta}(25 \mathrm{~nm}) / \mathrm{p}^{+}-\mathrm{n}$ junction diodes suffered severe degradation after the devices were annealed at $650^{\circ} \mathrm{C}$. This indicates that electrical measurement is a much more sensitive technique for barrier failure detection.

For the samples with a $500 \mathrm{~nm}$ oxide layer between the barrier metal and Si substrate, sheet resistance of the $\mathrm{Cu} / \mathrm{Ta}(25 \mathrm{~nm}) / \mathrm{SiO}_{2} / \mathrm{Si}$ and $\mathrm{Cu} / \mathrm{TaN}(25 \mathrm{~nm}) / \mathrm{SiO}_{2} / \mathrm{Si} \mathrm{sam}-$ ples remained constant up to at least $800^{\circ} \mathrm{C}$. Moreover, no signal relating to $\mathrm{Ta}-\mathrm{Si}$ or $\mathrm{Cu}-\mathrm{Si}$ compound was detected by XRD analysis. The different results between the $\mathrm{Cu} /$ barrier/SiO $/ \mathrm{Si}$ and $\mathrm{Cu} /$ barrier/Si samples imply that the $\mathrm{Si}$ substrate in the $\mathrm{Cu} / \mathrm{barrier} / \mathrm{Si}$ contact system acted as a $\mathrm{Cu}$-sink, which plays an important role in determining the thermal stability of the $\mathrm{Cu} /$ barrier/Si structure.
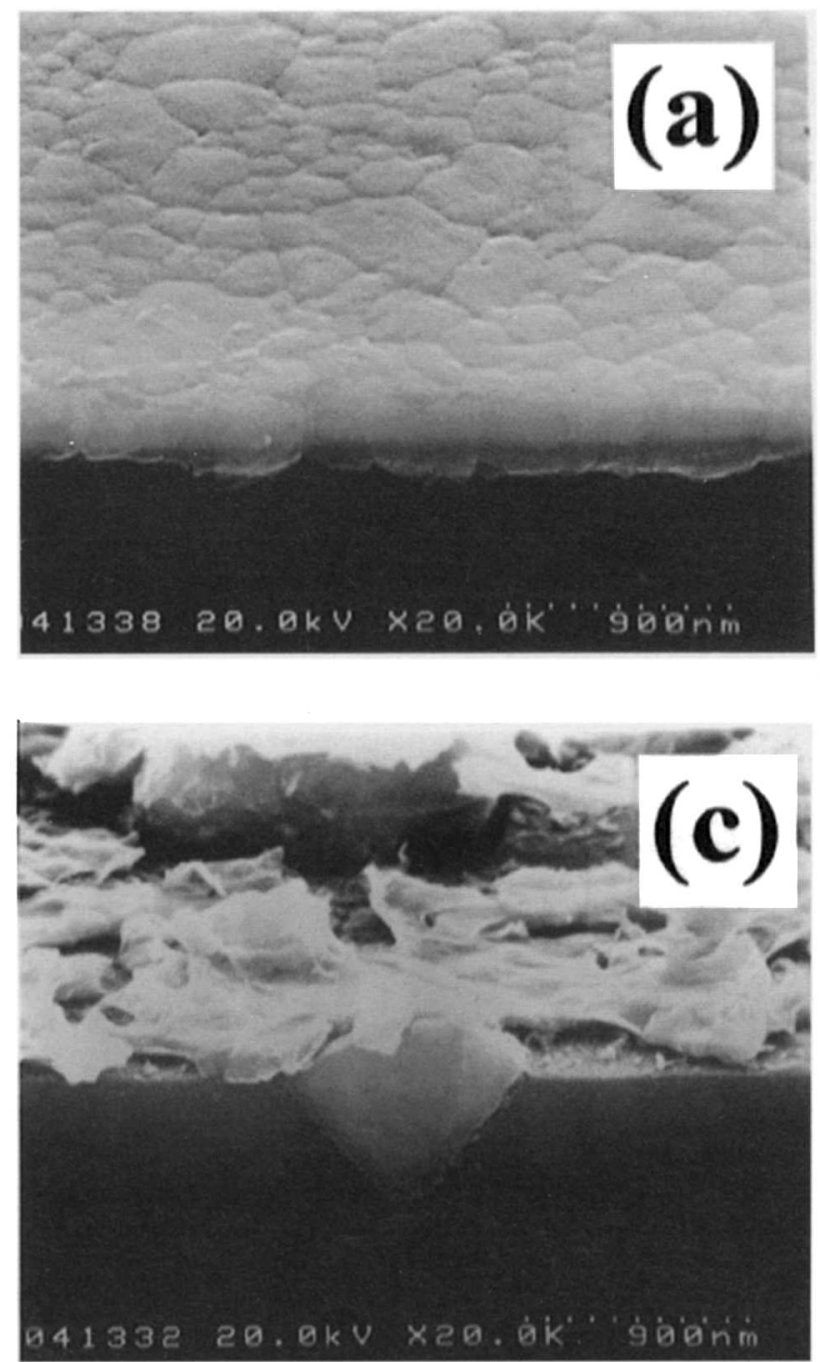

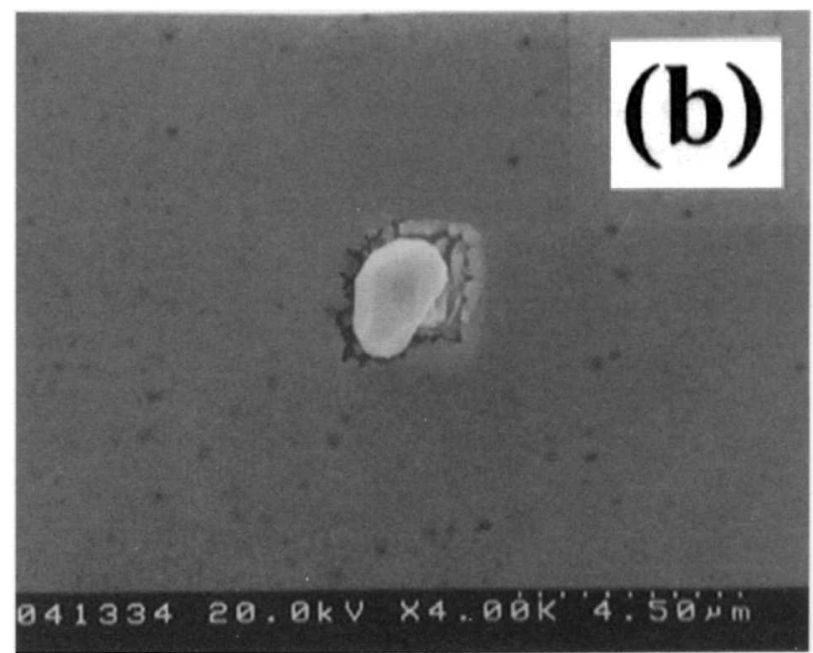

Fig. 11. SEM micrographs for the $\mathrm{Cu} / \mathrm{TaN}(5 \mathrm{~nm}) / \mathrm{p}^{+}-n$ diodes annealed at (a) and (b) $550^{\circ} \mathrm{C}$, and (c) $600^{\circ} \mathrm{C}$. The micrograph (a) was taken on a diode of low leakage current while (b) was taken on a severely degraded diode. 


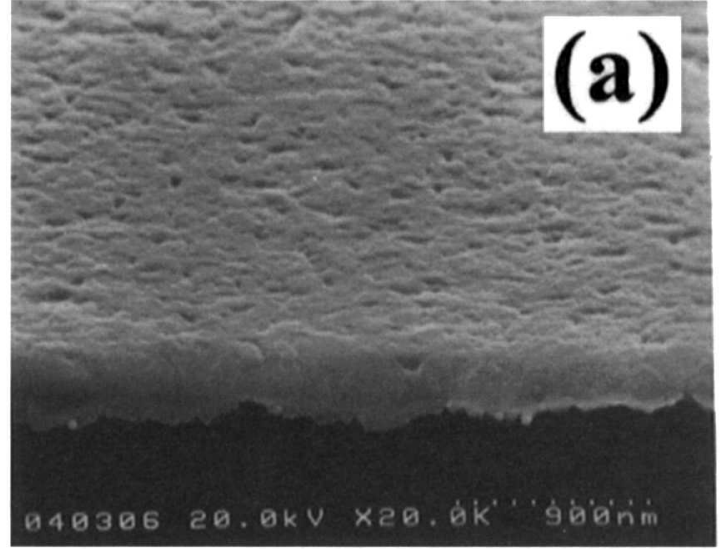

Fig. 12. SEM micrographs for the $\mathrm{Cu} / \mathrm{Ta}(5 \mathrm{~nm}) / \mathrm{p}^{+}-\mathrm{n}$ diodes annealed at $(\mathrm{a}) 500$ and $(\mathrm{b}) 550^{\circ} \mathrm{C}$.
Comparative results of thermal stability for the multilayer structures studied in this work based on XRD analysis are summarized in Table II.

SEM observation.-SEM was used to investigate the surface and cross-sectional morphology of the thermally annealed $\mathrm{Cu} / \mathrm{barrier} / \mathrm{p}^{+}-\mathrm{n}$ junction diodes. Figure 9 shows the surface morphology of $\mathrm{Cu} / \mathrm{TaN}(25 \mathrm{~nm}) / \mathrm{p}^{+}-\mathrm{n}$ junction diodes annealed at 700 and $750^{\circ} \mathrm{C}$. Surface morphology of the diodes remained stable after annealing at $700^{\circ} \mathrm{C}$ (Fig. 9a and b). After annealing at $750^{\circ} \mathrm{C}$, some of the diodes degraded severely (with high leakage current) while the others were only slightly degraded with reverse bias leakage current density less than $100 \mathrm{nA} / \mathrm{cm}^{2}$, as shown in Fig. 3. For those diodes showing only a slight degradation, surface morphology of the diodes is shown in Fig. 9c and $d$; only a number of small openings were observed on the surface. For those severely degraded diodes, Fig. 9e and $\mathrm{f}$ shows that there are highly localized protrusions on the diode's surface. Thus, failure of the devices is associated with these protrusions, which were presumably caused by $\mathrm{Cu}$ diffusion through the localized weak points in the TaN barrier layer. For the $\mathrm{Cu} / \mathrm{Ta}(25 \mathrm{~nm}) / \mathrm{p}^{+}-\mathrm{n}$ junction diodes, SEM micrographs revealed that the device's structure was able to remain stable after annealing at $600^{\circ} \mathrm{C}$, as shown in Fig. 10a; however, localized protrusions were found after annealing at $650^{\circ} \mathrm{C}$, as shown in Fig. $10 \mathrm{~b}$.

Figure 11 shows the SEM micrographs for the $\mathrm{Cu} / \mathrm{TaN}$ $(5 \mathrm{~nm}) / \mathrm{p}^{+}-\mathrm{n}$ diodes annealed at 550 and $600^{\circ} \mathrm{C}$. After annealing at $550^{\circ} \mathrm{C}$, the diodes with a low leakage current density nearly retained their structural integrity (Fig. 11a), while a few highly localized protrusions were found for the diodes with a large leakage current density (Fig. 11b). After annealing at $600^{\circ} \mathrm{C}$, dense localized protrusions were found on the surface of the annealed samples (Fig. 11c). For the $\mathrm{Cu} / \mathrm{Ta}(5 \mathrm{~nm}) / \mathrm{p}^{+}-\mathrm{n}$ diodes, SEM observation revealed that the device's structure basically remained stable after annealing at $500^{\circ} \mathrm{C}$ (Fig. $12 \mathrm{a}$ ). However, $\mathrm{Cu}$ penetrated the Ta barrier to form $\eta^{\prime \prime}-\mathrm{Cu}_{3} \mathrm{Si}$ precipitate after annealing at $550^{\circ} \mathrm{C}$. This precipitate extends into the Si substrate and out of the sample surface, as shown in Fig. 12b. Based on the results of SEM observation (Fig. 9, 10, 11, and 12) and electrical measurement (Fig. 2 and 3), we conclude that the electrical degradation for the thermally annealed $\mathrm{Cu} / \mathrm{barrier} / \mathrm{p}^{+}-\mathrm{n}$ junction diodes is closely related to the presence of highly localized defects in the barrier layers. This suggests that the failure of very thin Ta and TaN barrier is principally due to permeation of $\mathrm{Cu}$ atoms through the barrier layer via local weak points (including grain boundaries) during the process of thermal annealing.

\section{Conclusion}

Thermal stability of very thin sputtered Ta and reactively sputtered TaN films used as a diffusion barrier between $\mathrm{Cu}$ and silicon substrate was investigated. We found that thermal stability of the $\mathrm{Cu} /$ barrier/Si system depends on

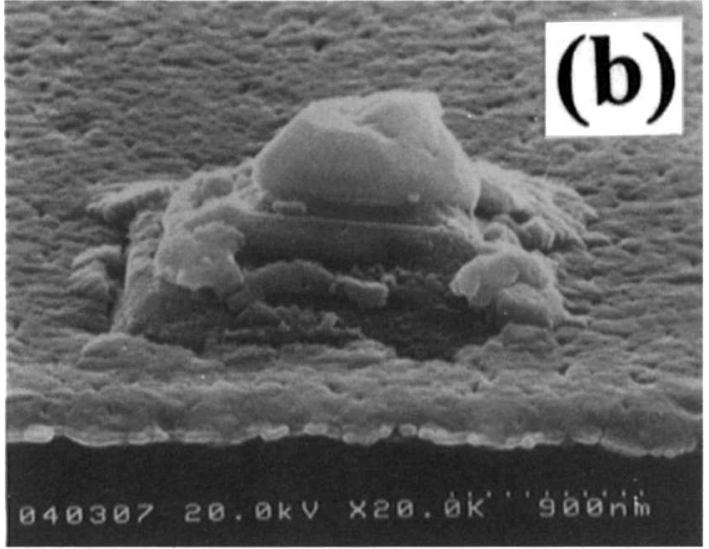

the barrier thickness and that the presence of $\mathrm{Cu}$ film on the $\mathrm{Ta}$ and $\mathrm{TaN}$ barrier surface of the barrier/Si structure accelerated the formation of Ta silicide. The $\mathrm{Cu} / \mathrm{Ta} / \mathrm{p}^{+}-\mathrm{n}$ junction diodes with a $25 \mathrm{~nm}$ thick Ta barrier were able to sustain a $30 \mathrm{~min}$ thermal annealing at temperatures up to $550^{\circ} \mathrm{C}$ without causing degradation to the device's electrical characteristics. For a $5 \mathrm{~nm}$ thick Ta barrier layer, thermal stability of the $\mathrm{Cu} / \mathrm{Ta} / \mathrm{Si}$ diodes was reduced to $450^{\circ} \mathrm{C}$. The barrier capability of the sputtered Ta layer can be effectively improved by incorporation of nitrogen in the Ta layer using reactive sputtering technique. The $\mathrm{Cu} / \mathrm{TaN} / \mathrm{p}^{+}-\mathrm{n}$ junction diodes with a $25 \mathrm{~nm}$ thick TaN barrier remained stable up to $700^{\circ} \mathrm{C}$. For a $5 \mathrm{~nm}$ thick TaN layer, thermal stability of the $\mathrm{Cu} / \mathrm{TaN} / \mathrm{p}^{+}-\mathrm{n}$ diodes was reduced to $500^{\circ} \mathrm{C}$. The failure of very thin $\mathrm{Ta}$ and $\mathrm{TaN}$ barrier was not related to Ta silicidation at the barrier/Si interface; instead, $\mathrm{Cu}$ atoms diffused through the barrier layer during the process of thermal annealing via local defects, such as grain boundaries and stress-induced weak points, leading to failure of the barrier layer.

\section{Acknowledgments}

This work was supported by the National Science Council (ROC) under contract no. NSC86-2215-E-009-040.

\section{Manuscript received April 7, 1998.}

The National Chiao-Tung University assisted in meeting the publication costs of this article.

\section{REFERENCES}

1. R. J. Gutmann, T. P. Chow, A. E. Kaloyeros, W. A. Lanford, and S. P. Murarka, Thin Solid Films, 262, 177 (1995).

2. N. Awaya, H. Inokawa, E. Yamamoto, Y. Okazaki, M. Miyake, Y. Arita, and T. Kobayashi, IEEE Trans. Electron Devices, ED-43, 1206 (1996).

3. V. M. Dubin and Y. S. Diiamand, J. Electrochem. Soc., 144, 898 (1997).

4. J. C. Chiou, K. C. Juang, and M. C. Chen, J. Electrochem. Soc., 140, 177 (1995).

5. J. C. Chiou, Y. J. Chen, and M. C. Chen, J. Electron. Mater., 23, 383 (1994).

6. C. A. Chang, J. Appl. Phys., 67, 566 (1990).

7. S. H. Corn and J. L. Falconer, J. Vac. Sci. Technol., A6, $1012(1988)$

8. Y. Shacham-Diamand, A. Dedhia, D. Hoffstetter, and W. G. Oldham, J. Electrochem. Soc., 140, 2427 (1993).

9. A. L. S. Loke, C. Ryu, C. P. Yue, J. S. H. Cho, and S. S. Wong, IEEE Electron Device Lett., EDL-17, 549 (1996).

10. J. C. Chiou, H. I. Wang, and M. C. Chen, J. Electrochem. Soc., 143, 990 (1996).

11. M.-A. Nicolet, Thin Solid Films, 54, 415 (1978).

12. M. Wittmer, J. Vac. Sci. Technol., A2, 273 (1984).

13. H. Ono, T. Nakano, and T. Ohta, Appl. Phys. Lett., 64, $1511(1994)$

14. W. K. Yeh, T. T. Wu, M. H. Tsai, S. C. Sun, J. C. Chuang and M. C. Chen, VMIC Proc., June 1996, p. 541.

15. S. D. Kim, S. G. Jin, M. R. Hong, and C. T. Kim, J. Elec- 
trochem. Soc. 144, 664 (1997).

16. S. Q. Wang, J. Appl. Phys., 73, 2301 (1993).

17. J. C. Chiou, K. C. Juang, and M. C. Chen, J. Electrochem. Soc., 142, 2326 (1995)

18. X. Sun, E. Kolawa, J. S. Chen, J. S. Reid, and M. A. Nicolet, Thin Solid Films, 236, 347 (1993).

19. K. Holloway and P. M. Fryer, Appl. Phys. Lett., 57, $1736(1990)$.

20. K. Holloway, P. M. Fryer, C. Cabral, Jr., J. M. E. Harper, P. J. Bailey, and K. H. Kelleher, J. Appl. Phys., 71, 5433 (1992).

21. E. Kolawa, J. S. Chen, J. S. Reid, P. J. Pokela, and M. A. Nicolet, J. Appl. Phys., 70, 1369 (1991).

22. T. Oku, E. Kawakami, M. Uekubo, K.Takahiro, S. Yamaguchi, and M. Murakami, Appl. Surf. Sci., 99, 265 (1996).

23. M. Takeyama, A. Noya, T. Sase, and A. Ohta, J. Vac. Scì. Technol., B14, 674 (1996).

24. R. G. Schad, F. Cardone, and L. Stolt, J. Appl.
Phys., 73, 301 (1993).

25. M. S. Angyal, Y. S. Diamand, J. S. Reid, and M. A. Nicolet, Appl. Phys. Lett., 67, 2152 (1995).

26. T. Vasilos and W. Kingery, J. Ceram. Soc., 37, 409 (1954).

27. B. S. Kang, S. M. Lee, J. S. Kwak, D. S. Yoon, and K. Baik, J.Electrochem. Soc. 144, 1807 (1997).

28. T. T. Wu, Masters Thesis, National Chiao-Tung University, Taiwan (1996).

29. JCPDS Files card no. 25-1280.

30. JCPDS Files card no. 38-0483.

31. A. Noya, M. Takeyama, K. Sasaki, and T. Nakanishi, $J$. Appl. Phys., 76, 3893 (1994).

32. A. Noya, M. Takeyama, K. Sasaki, E. Aoyagi, and K. Hiraga, J. Vac. Sci. Technol., A15, 263 (1997).

33. JCPDS Files card no. 32-1283.

34. JCPDS Files card no. 6-0594.

35. JCPDS Files card no. 4-0836.

36. JCPDS Files card no. 23-224.

\title{
Investigation of Boron Penetration Through Thin Gate Dielectrics Including Role of Nitrogen and Fluorine
}

\author{
Mitra Navi* and Scott T. Dunham** \\ Department of Electrical and Computer Engineering, Boston University, Boston, Massachusetts 02215, USA
}

\section{ABSTRACT}

This work examines boron penetration from $\mathrm{p}^{+}$polysilicon through $50-70 \AA$ gate dielectrics following $\mathrm{B}$ or $\mathrm{BF}_{2}$ implantation. Gate oxides were grown in $\mathrm{N}_{2} \mathrm{O} / \mathrm{O}_{2}$ mixtures with average nitrogen contents varying from 0 to $1.4 \%$. A series of capacitance-voltage measurements were used to determine the amount of boron penetration, and secondary ion mass spectroscopy measurements were carried out to measure the depth profiles of incorporated nitrogen and fluorine. In addition, to better understand the role of fluorine, experiments were carried out to investigate the redistribution of fluorine in the poly $/ \mathrm{SiO}_{2} / \mathrm{Si}$ system.

\section{Introduction}

Scaling of complementary metal-oxide semiconductor (CMOS) processes down to submicron channel lengths greatly improves device density and circuit speed but introduces many challenges in process technology. One difficulty is the scaling of the gate dielectric, particularly for the fabrication of $\mathrm{p}^{+}$polysilicon gates in $\mathrm{p}$-channel devices. The concern is the diffusion of boron through the gate oxide. Boron penetration from the $\mathrm{p}^{+}$-polysilicon gates can cause fluctuations in flatband voltage $\left(V_{\mathrm{FB}}\right)^{1}$ which are accompanied by increases in electron charge trapping and inverse subthreshold slope. ${ }^{2}$

The diffusivity of boron can be modified by many factors. Increased boron diffusivity is observed when fluorine or hydrogen is introduced in the oxide. ${ }^{3}$ In contrast, incorporation of nitrogen in $\mathrm{SiO}_{2}$ is $\mathrm{known}^{4,5}$ to reduce boron diffusivity. Injection of silicon interstitials in the oxide has also been suggested to decrease boron diffusivity. ${ }^{6}$

It has been proposed that boron diffusion increases with decreasing oxide thickness. ${ }^{7}$ However, recent work has found no thickness dependence..$^{3,8,9}$ Aoyama et al., ${ }^{3}$ who have carried out perhaps the most extensive set of experiments on boron penetration in thin oxides, found no oxide thickness dependence on boron diffusion in the absence of fluorine. However, in the presence of fluorine, they extracted higher B diffusion for thinner oxides. The difference was attributed to the fact that the boron diffusion strongly depends on fluorine content of the oxide, which was presumed to vary with thickness.

Although B diffusion is expected to depend locally on the oxide structure and composition, modeling to date has been generally limited to determining an effective average dif-

* Electrochemical Society Student Member.

** Electrochemical Society Active Member. fusivity as a function of processing conditions. ${ }^{5,7}$ To generate a predictive model, it is important to consider the underlying oxide composition and structure that results in the observed diffusivity. In order to help address these issues, we have conducted a series of experiments in which both boron diffusivity as well as the composition of the oxide were studied.

\section{Experimental}

MOS capacitors were fabricated on 4 in. silicon (100) wafers with background phosphorus doping of $2-4 \Omega \mathrm{cm}$. A field oxide of $0.6 \mu \mathrm{m}$ was grown and etched to define active areas $(100 \times 100 \mu \mathrm{m})$. Gate dielectrics were grown in pure $\mathrm{O}_{2}$ at $870^{\circ} \mathrm{C}$, pure $\mathrm{N}_{2} \mathrm{O}$ at $910^{\circ} \mathrm{C}$, or an $\mathrm{N}_{2} \mathrm{O} / \mathrm{O}_{2}$ at $870^{\circ} \mathrm{C}$ mixture. Undoped polysilicon was deposited at $625^{\circ} \mathrm{C}$ immediately following gate dielectric growth. The polysilicon was implanted to a dose of $5 \times 10^{15} \mathrm{~cm}^{-2}$, using $\mathrm{P}^{+}$at $40 \mathrm{keV}$ and $\mathrm{BF}_{2}^{+}$or $\mathrm{B}^{+}$at $25 \mathrm{keV}$. A low-temperature cap oxide of $0.5 \mu \mathrm{m}$ was deposited at $425^{\circ} \mathrm{C}$ to avoid outdiffusion of boron. Wafers were annealed at $900-1050^{\circ} \mathrm{C}$ for various times to ensure boron penetration. After removal of the cap oxide, the polysilicon was patterned and etched. Aluminum deposition followed by sintering was performed on some samples and capacitance-voltage measurements showed no difference between capacitors with and those without aluminum electrodes.

Capacitors were characterized using high-frequency $(100 \mathrm{kHz})$ capacitance-voltage (CV) measurements. In addition, secondary ion mass spectroscopy (SIMS) measurements were carried out ${ }^{\mathrm{a}}$ to quantify the amount of nitrogen and fluorine incorporation in the gate oxides, as well as in the polysilicon and substrate. 